European Journal of Business and Innovation Research

Vol.8, No.1.pp. 32-42, January 2020

Published by ECRTD-UK

Print ISSN: 2053-4019(Print), Online ISSN: 2053-4027(Online)

\title{
EXPLORING CRITICAL FACTORS INFLUENCING SUSTAINABLE FOOD CONSUMPTION: A CONCEPTUAL REVIEW
}

\author{
Chioma Dilichukwu Ifeanyichukwu \\ Department of Marketing, Nnamdi Azikiwe University, Awka. \\ cd.ifeanyichukwu@unizik.edu.ng \\ Ireneus Chukwudi Nwaizugbo \\ Department of Marketing, Nnamdi Azikiwe University, Awka. \\ ic.nwaizugbo@unizik.edu.ng
}

\begin{abstract}
Sustainable food consumption is consumption of foods/diets that meets the dietary needs of man, the society, environment, economy and culture. Everyday great amounts of food are produced, processed, transported by the food industry and consumed by us. Hence, a comprehensive model of determinants of the sustainability of consumption is developed and applied to food consumption. When discussing the problem of unsustainable consumption, there is a need to focus on consumers' behavior towards the decision making process. The sustainability of food consumption depends on individual consumer choices, but these individual choices are severely constrained by a range of factors. This paper is an attempt to profile these factors that affect sustainable food consumption. In addition, a research model is drawn up to aid further studies in this area.
\end{abstract}

KEYWORDS: sustainable food consumption, attitude, subjective norms, perceived behavioural control, economic factors, environmental factors, sensory factors

\section{INTRODUCTION}

Food consumption is obviously an important and unavoidable part of everyday consumption. Quality food is fundamental for human health and wellbeing. In addition, our modern economy have increasingly transformed food into a transnational commodity in the hands of a profit-driven, industrial food system, thus, too many food labels, confusion and information overload on food choices. This has resulted in the growing trend and negative impact on people's health and on the environment. Recently, there is a growing interest on an interdisciplinary research approach around "sustainable food consumption studies". The issue of sustainability is of great natural and economic concern. In the face of growing global population, there is an ardent need to focus specially on sustainability issues arising from food systems. Altering consumption patterns is one of the greatest challenges in the quest for environmentally sound and sustainable development in this $21^{\text {st }}$ century. Nigeria has a total population of over 200million people which is envisaged to increase in the next few years (Nwaizugbo and Ifeanyichukwu, 2016). Due to the growing population of the world, there has been need to increase food output in order to meet the growing 
European Journal of Business and Innovation Research

Vol.8, No.1.pp. 32-42, January 2020

Published by ECRTD-UK

Print ISSN: 2053-4019(Print), Online ISSN: 2053-4027(Online)

number of consumers, thus, placing great stress on natural resources. Sustainable consumption has been defined by the United Nations Commission on Sustainable Consumption (UNCSD) as the use of goods and services that responds to basic needs and brings a better quality of life while minimizing the use of natural resources, toxic materials and emissions of waste so as not to jeopardize the needs of future generations.

Nigeria has also been faced with recession and inflation in recent times. This has resulted to higher prices for goods and services, lower income and lower standard of living. Even the government has shown greater levels of interest in this area, thus, the Sustainable Development Goals (SDGs) which has four out of the seventeen elements talking of food, health and sustainable consumption. For instance, SDG 2 says Zero hunger, SDG 3 emphasizes Good Health and Well being, SDG 6 proposed Clean Water and sanitation and SDG 12 emphasized Responsible Consumption and Production (United Nations Development Program, 2015). Since the emergence of the United Nations Sustainable Development Goals (SDGs), every nation has keyed into it and made frantic deliberate effort towards its actualization, Nigeria not left out.

Sustainable food consumption was also seen to have market shares less than $1 \%$ when placed alongside other foods (MacGillvray, 2000). Willer and Kilcher (2012) noted that the markets for organically grown food products are small. The decision to consume or not to consume sustainable food products takes into account individual needs like taste, price, convenience and health (Meulenberg, 2003). 52 percent of consumers who were interested in purchasing sustainable products ended up not purchasing them due to lack of availability, inconvenience, price, habit and trust (Robinson and Smith, 2002). Studies (Macdiarmid, 2013; Vieux, Soler, Touazi \& Darmon, 2013) have also shown that some nutrient-dense diets are associated with higher GHGEs, some low cost foods were seen to have empty/low nutrient (Darmon \& Drewnowski, 2015) and some affordable low cost foods were not culturally acceptable (Malliot, Darmon \& Drewnowski, 2010). In discussing the problem of unsustainable consumption, there is perhaps a need to focus on individual consumers' decision making and behavior. This entails focusing on their attitudes, preferences, and choices for the sustainability of consumption. In this article, our aim is to explore the determinants of sustainable food consumption. This study adapted the theory of planned behaviour alongside few other variables that have been used by other researchers in studying sustainable food consumption. These variables are economic factors, cultural factors, health related factors, sensory factors and environmental factors.

\section{LITERATURE REVIEW}

Sustainable Food Consumption- Sustainable food consumption is consumption of foods/diets that meets the dietary needs of man, the society, environment, economy and culture. Everyday great amounts of food are produced, processed, transported by the food industry and consumed by us and these activities have direct impact on our health and the environment. A study by Horton (2003) found that in food shopping, green processes were advanced. More so, the places where shopping occurs is important- green commercial enterprises, organic markets, health food stores and so on. The Organization for Economic Cooperation and Development (OECD) in 2008 opined that consumption is a way of expressing status and identity, causing consumers to be very 
European Journal of Business and Innovation Research

Vol.8, No.1.pp. 32-42, January 2020

Published by ECRTD-UK

Print ISSN: 2053-4019(Print), Online ISSN: 2053-4027(Online)

conscious of their purchases but then peer pressure and social norms are most times dictates of consumption pattern. Seyfang (2003) also opined that current patterns of food consumption are unjust and unsustainable and needs to be transformed. Reisch, Eberle and Lorek (2013) opined that there are serious environmental issues which relates to food consumption and production (SCP). Approximately, 800 million people suffer from hunger and under consumption of food and a lack of access to safe and sufficient drinking water (Millstone and Lang, 2008). More so, 1billion to 1.5 billion people are overweight and between 300 to 500 million of them obese which shows a tendency in dietary shift towards more sugar, animal protein and trans fat. Diet and lifestyle related health problems such as cardio vascular diseases and diabetes are appearing even in age groups, thus an increase in health cost (Commission of the European Communities, 2007; British Cabinet Office, 2007). Food consumption is obviously an important and unavoidable part of everyday consumption. In addition, it is one of the areas of private consumption that are most important for environmental sustainability (European Environment Agency 2005). It has been estimated that approximately one third of households' total environmental impact is related to food and drink consumption (Danish Environmental Protection Agency 2002). Food consumption is a broad and diverse field and the environmental sustainability of private food consumption depends on several variables, such as the amount of beef in the diet, the production system (e.g., organic vs. conventional), and how and how far the food products are transported. Extant research suggests that currently the most effective ways that affluent consumers can increase the sustainability of their food consumption are to (1) reduce the amount of meat, especially beef, in their diet, (2) buy organic instead of conventionally produced food products, and (3) avoid food products transported by airplane (e.g., Carlsson-Kanyama \& Gonzalez 2009; Dabbert, Haring, Zanoli 2004). It is important to note that this research study focuses on only one of these important ways to increase the sustainability of food consumption which is choosing organic instead of conventional food.

Reisch, Eberle and Lorek (2013) also noted that food habits and preferences are shaped by cultural traditions, norms, fashion, psychological needs, personal food experiences, and exposure to the consumption context (that is, food availability and accessibility). More so, finances, time, work pattern and household decision making were seen to influence food consumption. However, some general food consumption trends evident in Nigeria and other European countries are increase in meat consumption, fresh diary product consumption and consumption of high processed meals (Food and Agriculture Organization of the United Nations, 2011). The increased sedentary lifestyles and modern diets are leading to rising obesity even among children and teenagers (World Health Organization, 2005). In addition, one third of food globally is wasted by consumers and the retail process (Gustavsson et al, 2011). For instance, a study on British household shows that 33 percent of food bought are discarded and 61 percent would have been eaten if they were managed well (Ventour, 2008). Likewise, Kranert et al (2012) recorded that 61percent of food waste in Germany originates from consumers and could be avoided. Reisch, Eberle and Lorek (2013) opined that the reason for such wastage could be poor menu planning, lack of food competence, poor knowledge of food freshness and storability, huge package sizes and quantity discounts which has made consumers buy more than they need at a time. Owen, Seaman and Prince (2007) have identified a range of key factors that influences consumers decision behaviour towards sustainable food. These factors range from convenience, cost, healthy eating habit, down to taste, quality, availability, variety, packaging and so on. 
European Journal of Business and Innovation Research

Vol.8, No.1.pp. 32-42, January 2020

Published by ECRTD-UK

Print ISSN: 2053-4019(Print), Online ISSN: 2053-4027(Online)

The Stern report calculated that agriculture contributes about 69percent of GHGs emission and of those agriculture related GHG, animals are responsible for 31percent and fertilizers for 38percent (Stern, 2006). In line with the above, the European Commission Assessment of Europeans consumption pattern concluded that food.

Extant literature have suggested few factors as influencing sustainable food consumption. These factors are discussed below;

Attitude- Vermeir and Verbeke (2006) argued that having a positive attitude toward sustainable products is basic in stimulating sustainable food consumption. Moreover, from their research study on sustainable food consumption among young adults in Belgium, they identified atttitude as the most important predictor for all respondents, irrespective of their value levels. According to Tanner and Kast (2003), attitudes and beliefs are powerful predictors of sustainable consumption. They also argued that positive attitudes toward environmental protection, fair trade, and local production are also major facilitators of sustainable consumption. In addition, Chan and Lau, (2001) identified a positive relationship between consumers' attitudes and behavioral intentions for green purchasing product (i.e organic food). With a positive attitude of consumers towards organic food, the health concerns (especially in families with children and infants) of traditionally produced foods come to the forefront.

Perceived Behavioural Control- This refers to the degree to which a person believes that they can control any given behavior. Tanner and Kast (2003) stated that perceived time barriers restrain one's motivation to buy green products where the results proved to be negatively associated. Perceived ease and difficulties about behavioral control and past experiences are influential in the emergence of behavioral intent and behavior. Moreover, in theory, the perceived behavioral control must occur before the intention is formed. Together with the perceived difficulties and eases in purchasing organic food products, past experiences are factors that determine behavioral intent and behavior. In many studies, it has been suggested that there is a positive relationship between the ability to control consumer behavior individually and the consumption of sustainable foods (Bryła, 2016; Kapuge, 2016; Lian, 2017; Savita \& Verma, 2017).

Subjective Norms- Subjective Norms (SN) has a direct impact on consumers' purchasing intentions and behaviors. Consumers' families, relatives, friends, and colleagues determine the subjective norms. Thus, the people around the consumers shape the attitudes of the individual (Singh \& Verma, 2017; Teng \& Lu, 2016; Yilmaz \& Ilter, 2017; Hansen et al., 2018). Subjective norms are important determinant of sustainable food consumption.

Economic Factors - Engel formulated a law which states that as income rises, the proportion of income spent on food falls even if absolute expenditure on food rises (Engel, 1857). The validity of Engel's law has been supported in many countries and at different times. Leon (1967) and Pasineti (1981) found an interaction between Engels law and technological progress in explaining sustainable development. The Keynesian theory which was propounded by John Keynes states that current real income is the most important determinant of consumption in the short run. That is to say, one spends according to how much income that comes in. Keynes just like Engel placed a greater level of emphasis on income forgetting other factors that may influence or determine 
European Journal of Business and Innovation Research

Vol.8, No.1.pp. 32-42, January 2020

Published by ECRTD-UK

Print ISSN: 2053-4019(Print), Online ISSN: 2053-4027(Online)

consumption. Duenesberry and Modigiliani introduced the concept of savings before consumption. He propounded the Life Cycle Hypothesis $(\mathrm{LCH})$ which strives to explain the consumption patterns of individuals. The LCH theory states that individuals plan their consumption and savings behaviour over their lifecycle. In addition, Alfred Marshall came up with the Marshallian Economic Theory which introduced price of substitute product alongside, income and price of the product. Since the introduction of these theories and models, several researchers have leveraged on them as a basis for their study. For instance, For Ifeanyichukwu and Nwaizugbo (2019); Moreria and Padrao (2004), income came into play. The low and high income groups tends to be similar in regards to several food groups consumption. These foods ranges from fruits and vegetables to nuts and grains. They also introduced education/literacy which tend to be the key element of better food pattern. Further, Akpan, Patrick, Udoka and Okon (2013) stressed the importance of salary, tax, family size, non-food consumption expenditure and income as determinants of sustainable food consumption. Studies like Kain, Vio and Albala (2003), Tonstad and Sivertsen (1997) have also identified the influence of socio-economic factors on individuals dietary intake and food consumption.

One of the social theories that have been used widely in sustainable food consumption is the Veblenian social-psychological model. This model places emphasis on norms and group memberships to have a greater effect on human behaviour. A consumer is a part and parcel of the society so can belong to several groups which can influence his buying behaviour. Researchers such as Cumbers, Davis and Mcmaster (2015), Sundie, Kenrick, Gnskevicus, Tybur, Vohs and Beal (2010) have leveraged on this theory. Shaw (2002) in his study pointed that it is the limited level of awareness that has led to negative attitude of consumers towards sustainable foods. Moon (2001) employed contingent valuation technique in his study to investigate consumer behaviour in the UK. The findings revealed that 13.3 per cent of the respondents were willing to accept sustainable foods even at higher prices, whereas 13.8 per cent of the participants will buy sustainable foods when they are offered at lower prices. The findings of Ifeanyichukwu and Nwaizugbo (2019) revealed that Income, Price of a product, social groups, education, price of substitute product are the socio-economic determinants of sustainable food consumption in Nigeria.

Cultural Factors- Past research studies have mentioned that culture and geographic regions also influence consumer attitude towards Sustainable foods (Bredahl, 2001; Curtis, 2004; Gaskell, 2004). The World Health Organization (WHO) emphasizes the importance of considering social, cultural, political, physical and structural influences for effective prevention and management of overweight and obesity (WHO, 2000). Thus, the importance of exploring cultural influences on food behaviour. The most important elements of culture are language, religion, values, attitudes, customs and different norms of the group or society. When we think about cultural models, we interpret different combinations of these elements. Research carried out by Nemeth, Rudnak, Ymeri and Fogarassy (2019) has shown the significant importance of culture in sustainable food consumption. The study found that dietary choices are complex decisions that have a significant strong cultural underpinning for sustainable eating and community values which can also strongly influence the development of the local food supply practices. Liobikiene, Mandravickait and Bernatoniene (2016) also revealed how cultural aspects contribute to purchase 
European Journal of Business and Innovation Research

Vol.8, No.1.pp. 32-42, January 2020

Published by ECRTD-UK

Print ISSN: 2053-4019(Print), Online ISSN: 2053-4027(Online)

behavior. It is reported that there is no significant relationship between personal norms and green food purchases (Tanner \& Kast, 2003). Nevertheless, personal norm can be influenced by the value a person carries which may come or developed by cultural or religious value. Human values are referred to as relatively stable beliefs about the personal or social desirability of certain behaviours and modes of existence. Values express the goals and needs that motivate people in appropriate ways to attain these goals/needs. Values can play an important role in the consumer decision process, like product choice and brand choice (Vermeir \& Verbeke, 2006) numerous studies have linked ethical or sustainable behaviour to personal values (Vermeir \& Verbeke, 2006). Religious values sometimes influence behaviour towards certain action. Personal factors (ignorance of sustainable products) or situational (lack of sustainable products in local retail outlets) factors inhibit the purchase of sustainable foods (Vermeir and Verbeke, 2008).

Sensory factors - According to Hulten (2011), a sensory experience supports individual value creation and refers to how individuals react when a firm interacts, and supports their purchase and consumption processes through the involvement of the five human senses in generating customer value, experiences and brand as image. Some researchers have identified with the power of smell (Buck, 2005). A research carried out by Bucks and Axel (1991) has shown that humans have the ability to recognize as many as 10,000 different scent combination but they may experience difficulty identifying the scent by name (Lawless and Engen, 1977). Ifeanyichukwu and Abude (2018) also emphasized the role of the senses- sight, sound, taste, touch, smell- on customer patronage and consumption of food. Sound is a particular auditory effect produced by a given cause. Also, the effect of sound symbolism (sound produced by objects) cannot be neglected because even as one reads a word, one hears that word as well. Yorkston and Menon (2004) and Klink (2000) opined that frosh brand ice cream sounds creamier than frish brand ice cream. A brand name should sound congruent with the expectation of consumers for brand evaluation to be positive. Therefore, brand names that appeals to the ear should be used. Taste can be sweet, bitter, sour, salty or savoury and the sense organ for taste is the tongue. As little as that organ is, yet so powerful. Hoch and Ha (1986) argued that taste is susceptible to external influences- physical attributes, brand name, product information, nutritional information etc. Brand names also affect perceived taste. Colours and shapes are the first way of differentiation and identification of a product. Vision is powerful as it creates attention, awareness and image. A visual stimulus builds strong store brands. Further, visual sense has been shown to be of great significance when verbal material is absent, creating a perception of quality which has a direct impact on the building of a strong brand. This is also emphasized by Messaris (1997) who argues that the sense of sight, beside the purpose of receiving attention, can elicit an emotional response towards a product and other things. Studies such as Seaman and Prince (2007) have argued that sensory factors such as taste leads to sustainable food consumption. Bryla (2016) also emphasized the importance of superior taste on sustainable food consumption.

Environmental Factors - This is concerned with protecting and maintaining environmental resources for future generations. These environmental issues are temporary or permanent changes to the atmosphere, water and land due to human activities which can result in impacts that may be either reversible or irreversible. Many environmental issues affects sustainability, for example loss of biodiversity due to economic development, deforestation due to the destruction of natural 
European Journal of Business and Innovation Research

Vol.8, No.1.pp. 32-42, January 2020

Published by ECRTD-UK

Print ISSN: 2053-4019(Print), Online ISSN: 2053-4027(Online)

habitats causing animals to migrate to suitable environment. Many of these environmental issues affecting food consumption are not well known to consumers. Consumers are increasingly becoming aware of the environmental issues as a result of food consumption. Many a times, they are faced with questions like, Should I consume foods in paper or plastic wrappers? Should I drink bottled water or filtered water? And so on. Key literatures have identified environmental factor as a key determinant to sustainable food consumption. Studies like Garcia-yi (2014); Yadav and Pathak (2016); Ueasangkomsate and Santiteerakul (2016). Persson (2014) also looked at environmentally friendly food alternatives. Bryla (2016) study on ecological character of the product emphasized the consumers awareness and need to purchase a product that is ecologically and environmental friendly. Lin and Huang (2012) also opined that consumers with high environmental concern support green products more. Kumar and Bipuls (2013) study has helped in understanding the relative strength of determinants of purchase intention with regard to environmentally sustainable products. Consumers who are concerned about the environment are more willing to pay a premium for green products (Tanner \& Kast, 2003). It is possible that consumers make an environmentally friendly choice more willingly when other motives such as finance and health are added to their environmental concerns. Arguments have been previously made that consumers are most likely to adopt any type of pro-environmental behaviors where cost and/or inconvenience are minimized (Tilikidou, 2005). Education has been found to be a positive antecedent of pro-environmental purchase. (Tilikidou, 2005). Environmental knowledge has been rather neglected as a possible correlate of purchasing behavior. Vermeir \& Verbeke, (2006) Study has shown few consumers to have a high awareness or comprehension of the real sustainable characteristics of food products because the benefits of sustainable food products are often poorly communicated to consumers, so that they are unable to make informed purchasing decisions in accordance with their budget and/or conscience. Ecologically conscious consumers are people with relatively high levels of education and income (Tilikidou \& Delistavrou, 2005). There has been argument as to whether knowledge may be considered as a direct motive to behaviour. Environmental knowledge has been found to be positively related to environmental behaviour (Tanner \& Kast, 2003). It has been determined that environment have an impact on organic food consumption. People living in cities have come forward were seen to have more environmental knowledge than the rest (Lian, 2017).

Health-related Factors- Health and well being are important factors in sustainability. Important measures include life expectancy and infant mortality (Smil, 2007). Many factors have been seen to contribute to human health. Factors such as access to safe and healthy foods, access to clean drinking water, safe waste disposal and an environment without harmful substances. Kriwy and Mecking(2011) reported that health consciousness has a stronger association with organic food consumption. Most key literatures have reported health related factors/consciousness as a key determinant of sustainable food consumption. Key literatures like Seaman and Prince (2007), Ueasangkomsate and Santiteerakul (2016) have studied the effect of health related factors on sustainable food consumption. Yadav and Pathak (2016) and Smith and Paladino (2010) studies emphasized that health consciousness positively influenced the consumers intention to purchase organic/sustainable foods. Bryla (2016) also emphasized the importance of health concern on sustainable food consumption. 
Fig 1 : Research Framework

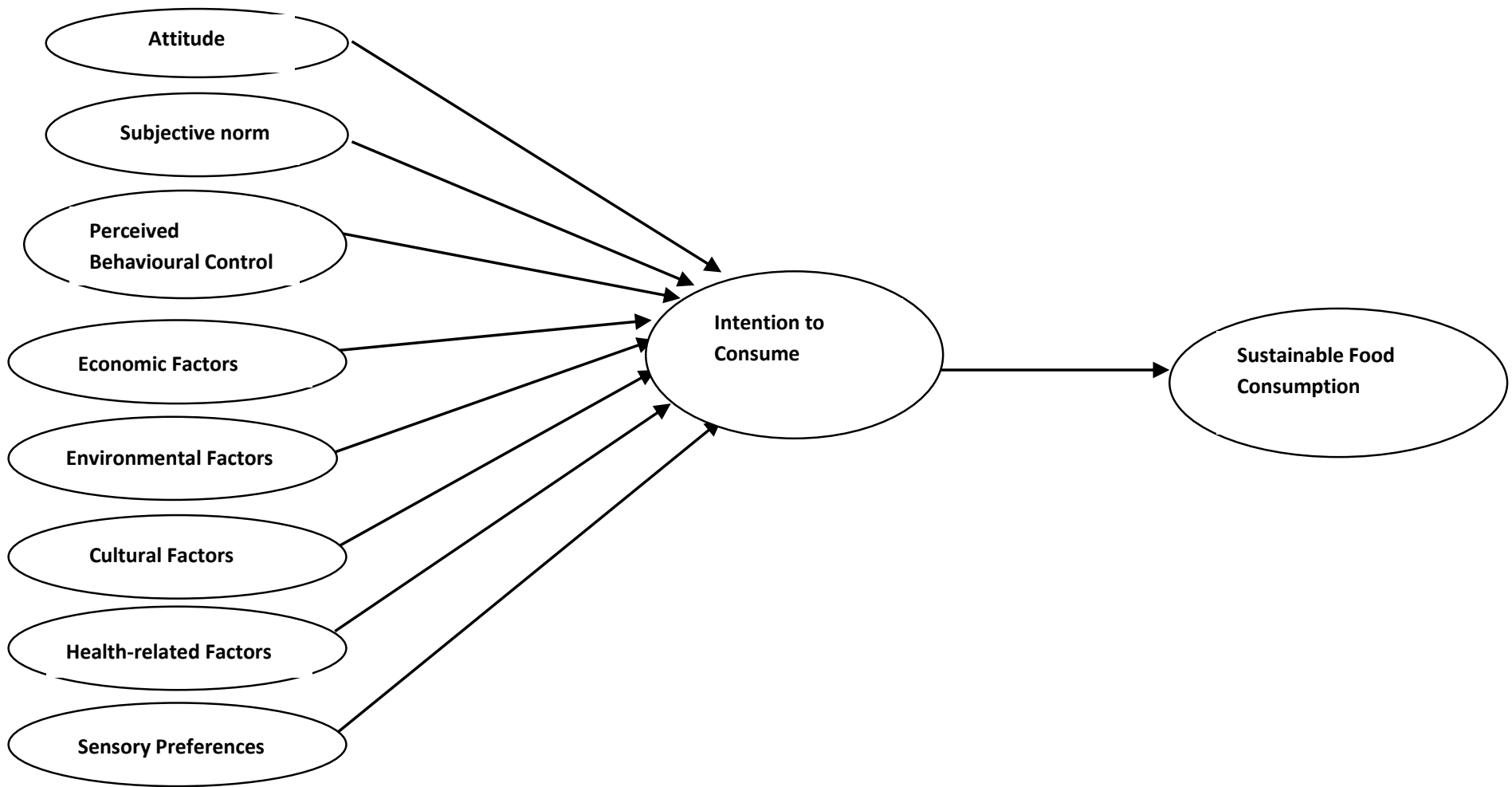

Source: Researchers conceptualization

\section{CONCLUSION}

The factors covered in this review go a long way towards explaining the determinants of sustainable food consumption. Overall, the review gives us an important insight for explaining sustainable food consumption behaviour. Also, the research model propounded in this review can be used for further empirical studies in the subject of the study.

\section{REFERENCES}

Al-Swidi, A., Augue, S. M. R; Hafeez, M. H \& Shariff, M. N. M (2014). The role of subjective norms in theory of planned behaviour in the context of organic food consumption. British Food Journal, 116(10), 1561-1580

Akpan, S.B; Patrick,I.B; Udoka, SJ and Okon, U.E (2013). Determinant of Food Consumption Expenditure among Agro based Firms Workers in Southern Nigeria: Simultaneous Equation Approach. Asian Journal of Agricultural Extension, Economics and Sociology, 2(1)

British Cabinet Office (BCO) (2007). Food: An analysis of the issues. London: BCO.

Bryla, P. (2016). Organic Food Consumption in Poland: Motives and Barriers Appetite. 1(5), 737746. 
European Journal of Business and Innovation Research

Vol.8, No.1.pp. 32-42, January 2020

Published by ECRTD-UK

Print ISSN: 2053-4019(Print), Online ISSN: 2053-4027(Online)

Buck,L (2005). Unraveling the Sense of Smell (Nobel Lecture). Angewandte Chemie, International Edition, Vol 44(38).

Buck, L. \&Axel,R (1991). A novel Multigene Family May Encode Odorant Receptors: A Molecular Basis for Odour Recognition, 65 (1).

Chan, R.Y. \& Lau, L.B. (2001). "Explaining green purchasing behavior: a cross-cultural study on American and Chinese consumers", Journal of International Consumer Marketing, 14 (2/3), 9-40.

Chang, S.H. (2015). The influence of green viral communications on green purchase intentions: The mediating role of consumers susceptibility to interpersonal influence, 7.

Commission of the European Communities (CEC) (2017). White paper on a Strategy for Europe on Nutrition, Overweight and Obesity Related Health Issues. European Commission. (A. Elbehri, Ed). Rome Italy: Food and Agriculture Organization of the United Nations.

Drewnowski, A. (2017). Sustainable Healthy Diets: Models and Measures. Springer International Publishing D01 10.10071978-3-319-55942-1-2

Engel, E(1857). The production and Consumption Conditions of the Kingdom of Saxony: Cost of Living in Belgian Working Class Families.

Food and Agricultural Organization of United Nations (FAO) 2011. Biodiversity for a world without hunger. www.fao.org/biodiversity-homlen) retrieved10th March 2018.

Garcia Y. J (2014). Market Based Instrument for the conservation of underutilized crops; sustainability, 6.

Gustavsson, J. Cerderberg, C; Sonnessson, U. Orrerdijk, R; and Maybeck, A (2011). Global Food Losses and Food Wastage, Rome.

Hansen, T., Sørensen, M. I., \& Eriksen, M. L. R. (2018). How the interplay between consumer motivations and values influences organic food identity and behavior? Food Policy, 74, 3952. http:// dx.doi.org/10.1016/j.foodpol.2017.11.003

Horton, D. (2003). Green Distinctions: The performance of identity among environmental marketing Strategies, Practice, theory and research, Haworth

Hulten, B (2011). Sensory marketing : The multi-Sensory Brand Experience Concept. European Business Review, 23(3).

Ifeanyichukwu, C.D and Nwaizugbo, I.C (2019). The Effect of Socio-Economic Factors on Sustainable Food Consumptin in Developing Economies. British Journal of Marketing Studies, Vol 7 (7), 13-19

Ifeanyichukwu, C.D and Abude, P (2018). The Role of Sensory Marketing in Achieving Customer Patronage in Fast Food Restaurants in Awka. International Research Journal of Management, IT and Social Sciences, Vol 5(2),155-163 DOI : 10.21744/irjmis.v5i2.632

Klink, R.R (2000). Creating Brand Names with Meaning: The use of Sound symbolism, marketing letters, Vol 11.

Kapuge, K. D. L. R. (2016). Determinants of organic food buying behavior: special reference to organic food purchase intention of Sri Lankan customers. Procedia Food Science, 6, 303308. http:// dx.doi.org/10.1016/j.profoo.2016.02.060. 8 8/8 Food Sci. Technol, Campinas, Ahead of Print, 2018 The awareness of organic food consumption

Kranert, M.; Hafner, G.; Brarbosz, J.; Schneider, F.; Lebersorger, S.; Schuller, H. and Leverenz, D. (2012). A search for the amount of food waste and Recommendations to decrease the food waste rate in Germany. Stuttgart: University of Stuttgart Germany. 
European Journal of Business and Innovation Research

Vol.8, No.1.pp. 32-42, January 2020

Published by ECRTD-UK

Print ISSN: 2053-4019(Print), Online ISSN: 2053-4027(Online)

Lawless, H \& Engen, T (1977). Associations to Odour: Interfernce, Mnemonics and Verbal Labelling. Journal of Experential Psychology : Human Learning and Memory, 3(1).

Leon, P(1967). Structural Change and Economic Growth: A Theoretical Essay on the Dynamics of the Wealth of Nations. Cambridge University Press, ISBN 0-521-23607

Lian, S. B. (2017). What motivates consumers to purchase organic food in Malaysia? Asian Social Science, 13(9), 100-109. http://dx.doi. org/10.5539/ass.v13n9p100.

Lin, P. and Huang, Y. (2012). The Influence Factors on Choice Behaviour regarding Green Products based on the Theory of Consumption Values. Journal of Cleaner Production, Vol 22(1) pp 11-18.

McDermott, M.S; Madalyn .O., Alexander .S., Thomas .S., Eleanor J. B., Tim .C. , Don .I. , Peter .C. and Rajeev .S. (2015). The theory of planned behaviour and discrete food choices: a systematic review and meta-analysis . International Journal of Behavioural nutrition and physical Activity vol 12(162)

Nemeth ,N. , Rudnak, I., Ymeri, P. and Fogarassy, C. (2019). The Role of Cultural Factors in Sustainable Food Consumption-An Investigation of the Consumption Habits among International Students in Hungary. Sustainability , 11, 3052; doi:10.3390/su11113052

Nwaizugbo, I.C \& Ifeanyichukwu, C.D (2016). Understanding Consumers Behaviour towards Online Shopping: A study of Online Shoppers in Anambra State Nigeria. International Journal of Sales, Retailing and Marketing, Vol 5, Issue 2

OECD (2008). Promoting Sustainable Consumption: Good Practice in OECD countries. OECD Publications, France.

Owen, L.; Seaman, H., and Prince, S. (2007). Public Understanding of Sustainable Consumption of Food: A report to the department of Environment, Food and Rural Affairs. Opinion Leader. Defra, London.

Passinetti, L.(1981). Keynes and the Cambridge Keynesians: a Revolution in Economics to be Accomplished, Cambridge University Press

Persson, A. (2014). Determinants of Sustainable Food Consumption. University of Gotthenburg Publisher Master Thesis in Marketing and Consumption

Reisch, L. A; Eberle, U. and Lorek, S. (2013). Sustainable Food Consumption: An Overview of Contemporary Issues and Policies. Sustainability Science, Practice and Policy Journal, $\quad 9(2)$

Savita, U., \& Verma, V. (2017). Influence of attitudes and subjective norms on intention to buy organic food: a literature review. In U. Arora, A. Verma \& S. Singh (Eds.), Management insight - A glimpse of contemporary research (pp. 455-468). New Delhi: DBH Publishers and Distributors.

Seyfang G. (2003). Growing Cohesion Communities, one favour at a time; Social exclusion, active citizenship. International Journal of Urban and Regional Research, 27(3)

Singh, A., \& Verma, P. (2017). Factors influencing Indian consumers' actual buying behaviour towards organic food products. Journal of Cleaner Production, 167, 473-483. http://dx.doi.org/10.1016/j. jclepro.2017.08.106.

Tanner, C., \& Kast, S. W. (2003). Promoting Sustainable Consumption: Determinants of Green Purchases by Swiss Consumer, Psychology \& Marketing, 20(10), pp.883-902. 
Teng, C. C., \& Lu, C. H. (2016). Organic food consumption in Taiwan: Motives. involvement. and purchase intention under the moderating role of uncertainty. Appetite, 105, 95-105. http://dx.doi.org/10.1016/j. appet.2016.05.006. PMid:27178878.

Tilikidou, I. (2005). The Effect of Knowledge and Attitude upon Greek's Pro-Enviromental Purchasing Behavior. Corporate Social Responsibility and Enviromental Management, 14, 122.

Tilikidou, I., \& Delistavrou, A. (2005). Pro-environmental purchasing behavior: the inhibiting influence of the materialistic values

Ueasangkomsate, P. and Santiteerakul, S. (2016). A study of Consumers' Attitudes and Intention to Buy Organic Foods for Sustainability. Procedia Environmental Sciences, Vol 34, pp 423-430

Ventour, L. (2008). The food we waste, Waste and Resource Action Program. Banbury: UK.

Vermeulen, S. J. Campbell, B. M and Ingram J. S. I (2012). Climate Change and Food Systems Annual Rev. Environmental Resource, 37 pp 195-222.

Vermeir, I, and Verbeke, W. (2008). Sustainable Food Consumption among young adults in Belgium: Theory of Planned Behaviour and the role of confidence and values. Ecological, Economics, Elseviet, 64(3), 542-553

World Health Organization World Bank(2015). Overweight and Obesity Fact Sheet. www.who.int/mediacentre/factsheets/fs311/en/ Retrieved on $10^{\text {th }}$ March 2018

Yadav, R; and Pathak G. S (2016). Organic Food Consumption in Taiwan: Motives, Involvement and Purchase Intention under the Moderating Role of Uncertainty, Appetite, Vol 105, pp 95-105

Yorkston, E \& Menon, G (2004). A Sound Idea? Phonetic Effects of Brand Names on Consumer Judgements. The Journal of Consumer research, 31 (1). 